\title{
Article \\ Cover Crop and Pruning Residue Management to Reduce Nitrogen Mineral Fertilization in Mediterranean Vineyards
}

\author{
Antonino Pisciotta *(D), Rosario Di Lorenzo, Agata Novara (D), Vito Armando Laudicina (D), Ettore Barone (D), \\ Antonino Santoro, Luciano Gristina and Maria Gabriella Barbagallo
}

check for

updates

Citation: Pisciotta, A.; Di Lorenzo, R.; Novara, A.; Laudicina, V.A.; Barone, E.; Santoro, A.; Gristina, L.; Barbagallo, M.G. Cover Crop and Pruning Residue Management to Reduce Nitrogen Mineral Fertilization in Mediterranean Vineyards. Agronomy 2021, 11, 164 https://doi.org/10.3390/ agronomy11010164

Received: 4 December 2020

Accepted: 14 January 2021

Published: 16 January 2021

Publisher's Note: MDPI stays neutral with regard to jurisdictional clai$\mathrm{ms}$ in published maps and institutional affiliations.

Copyright: $(2021$ by the authors. Licensee MDPI, Basel, Switzerland. This article is an open access article distributed under the terms and conditions of the Creative Commons Attribution (CC BY) license (https:// creativecommons.org/licenses/by/ $4.0 /)$.
Department of Agricultural, Food and Forest Sciences, University of Palermo, Viale delle Scienze, 90128 Palermo, Italy; rosario.dilorenzo@unipa.it (R.D.L.); agata.novara@unipa.it (A.N.); vitoarmando.laudicina@unipa.it (V.A.L.); ettore.barone@unipa.it (E.B.); santoro1974@gmail.com (A.S.); luciano.gristina@unipa.it (L.G.);

mariagabriella.barbagallo@unipa.it (M.G.B.)

* Correspondence: antonino.pisciotta@unipa.it

\begin{abstract}
This paper aimed to study the effect of temporary cover crop and vine pruning residue burial as alternative practices to conventional tillage on soil nitrate $\left(\mathrm{NO}_{3}-\mathrm{N}\right)$ availability and grapevine performance in the short term. The trial was carried out in a rain-fed vineyard (Vitis vinifera $\mathrm{L} ., \mathrm{cv}$ Grecanico dorato/140 Ruggeri) located in a traditional Mediterranean viticultural area $\left(37^{\circ} 32^{\prime} 48^{\prime \prime} \mathrm{N}\right.$; $13^{\circ} 00^{\prime} 15^{\prime \prime} \mathrm{E}$ ) in Sicily (Italy). Conventional tillage (CT) soil management was compared with winter cover crop (CC), conventional tillage plus buried pruning residue (CT + PR), and winter cover crop plus buried pruning residue $(C C+P R)$ management treatments. Two fertilizer treatments $\left(92 \mathrm{~kg} \mathrm{ha}^{-1}\right.$ of $\mathrm{N}$ as urea and $0 \mathrm{~kg} \mathrm{ha}^{-1}$ ) were applied to the four soil management treatments. Vicia faba L. was the selected leguminous cover crop species, which was seeded in autumn and buried in spring at the same time as vine pruning residues. The soil $\mathrm{NO}_{3}-\mathrm{N}$ content was monitored, and vine vegetative growth, yield, and must quality were assessed over two seasons. Results showed that $\mathrm{NO}_{3}-\mathrm{N}$ availability strongly differed between fertilized (F) and unfertilized (UF) plots and years and among treatments. A positive effect of winter leguminous $\mathrm{CC}+\mathrm{PR}$ on the Grecanico dorato grapevine performance was observed. In the UF vineyard, grape fertility, yield, Ravaz index, and total soluble solids were significantly higher in CC + PR vines than in other treatments, thus showing the reliability of reducing $\mathrm{N}$ mineral fertilization and related risks of excess nitrate in groundwater. The possibility of increasing the overall sustainability of rain-fed vineyards in a semiarid agro-ecosystem, without negative effects on grape and must quality, is also demonstrated.
\end{abstract}

Keywords: soil nitrate availability; grape yield and quality; vine vigor; sustainable soil management

\section{Introduction}

Over the past decades, conventional agriculture in the semiarid Mediterranean environment has generally improved crop yield but has come at great environmental costs due to high $\mathrm{N}$ fertilizer inputs and intensive management of agricultural systems, including burning of pruning material [1,2]. In this environment, where water supply is limited, soil surfaces are managed to preserve water. Frequent tillage controls weeds and prevents soil cracking [3,4] but increases soil compaction, damages vine roots, reduces vegetation cover, and increases water runoff, sediment erosion, soil organic matter mineralization, and nitrate leaching $[5,6]$. As a result, soil degradation of intensively managed lands such as vineyards has become a major problem in the Mediterranean [7,8]. Among the strategies to increase environmental sustainability in orchards, cover cropping, together with other nature-based solutions, is recognized as an effective sustainable practice to reduce the impact of agriculture on the environment [9].

In line with the European Union strategies, aimed to minimize excess nitrate in groundwater and avoid the depletion of organic matter in soil, the Sicilian government adopted rules that prohibit the burning of vine pruning residues and promote the use of cover 
crops in vineyards. Recently, the Sicilian government introduced the agro-environmental payment system as part of the Best Agricultural Practices program [10].

Among the suggested best practices, incorporating pruning residue, often simply burned, into the soil can be a low-cost, sustainable practice that may increase soil organic matter and help reduce $\mathrm{N}$ loss due to microbial lignin degradation [11]. Furthermore, vine pruning residue has long-lasting effects due to its slow decomposition caused by the high content of cellulose and lignin and the high C: $\mathrm{N}$ ratio [12].

Introducing leguminous cover crops into vineyard soil management may also improve several physical and chemical properties of soil, including lowering the risk of soil erosion.

Furthermore, cover crop, through the decomposition of its buried biomass, contributes to nutrient release during winter and to a decrease in nutrient loss, either dissolved in water runoff or lost in sediment erosion, thus helping in reducing external $\mathrm{N}$ input use [13-16].

Leguminous cover crops may therefore supply vine N needs [17], but in areas of low rainfall, low soil organic matter, and high grape yields, additional sources of $\mathrm{N}$ may be necessary [18]. However, their use remains largely underexploited [9] due to the perception that cover crops can compete strongly for soil water content, affecting the grapevine water status and reducing vegetative growth, yield, and berry quality, as reported under different soil and climatic situations [19-21]. In woody fruit species such as grapevine, yield components are built over two years: bud fertility is determined in year one, and inflorescence, flowers' development, and fecundation as berry number and growth are determined in year two. So vine physiology (water and nitrogen) and climatic conditions affect yield components over two years.

Even if grapevines' nutrient requirements are well known and may be considered lower [22] compared to other fruit trees or annual crops, there is still a lack of knowledge of how leguminous cover crop influences the availability and absorption of nitrate in vineyard systems throughout the year. It should also be determined whether or not the adoption of a leguminous cover crop can result in an excessively high nitrate content in the soil as a combined effect of $\mathrm{N}$ fixation and fast cover crop mineralization after burying and how all this can affect soil $\mathrm{N}$ availability over the vine vegetative season. Since soil $\mathrm{N}$ availability may not always match with the vines' $\mathrm{N}$ uptake pattern, special attention must be given to the fate of soil nitrate, as affected by the vineyard floor management techniques, avoiding contrasting effects of vigor increase or stress on grape yield and quality [23].

To explore the possibilities to reduce $\mathrm{N}$ mineral fertilization in Mediterranean vineyards without affecting grape yield and quality, a two-year study was carried out in a semiarid Sicilian vineyard system, exploring the potential benefits of the combined use of leguminous cover crops and vine pruning residues. The underlying hypothesis was that cover crops can satisfy vine nitrogen needs and that pruning residue can temporarily immobilize any nitrogen excess.

The main aim of this study was to study the seasonal evolution of soil nitrate content and the associated vine physiological functioning, as affected by alternative and sustainable vineyard floor management and fertilization solutions.

\section{Materials and Methods}

\subsection{Study Area and Experimental Design}

The effects of different soil management and fertilization practices on soil and grapevines were investigated in 2010 and 2011 in a mature commercial Vitis vinifera L., cv. Grecanico dorato/140 Ruggeri rootstock vineyard located in the UE Protected Designation of Origin (PDO-IT-A0786) Menfi winegrowing district, southwest of Sicily, Italy ( $37^{\circ} 32^{\prime} 48^{\prime \prime} \mathrm{N}$; $13^{\circ} 00^{\prime} 15^{\prime \prime} \mathrm{E} ; 100 \mathrm{~m}$ a.s.l.), on a flat area. Soils around the study area are at high risk of nitrate contamination according to the Map of Nitrate-Vulnerable Zone in Sicily issued in 2005 by the Sicilian regional government. The vineyard was established in 2000 in an 80-cm-deep Vertisol-Calcic-Gleyic soil [24] (23\% sand, 37\% silt, and 40\% clay; $\mathrm{pH}=8$; $\mathrm{CaCO}_{3}=22 \%$, total $\mathrm{N}=0.101 \%$, and $15.7 \mathrm{~g} \mathrm{~kg}^{-1}$ soil organic matter). According to Köppen and Geiger [25], the climate of this area is classified as Csa and can also be defined as semi- 
arid, based on the Thornthwaite moisture index $(\mathrm{Im}=-33)$. Data regarding the monthly average temperature and precipitation sum during the entire trial period were obtained by a weather station positioned in the proximity of the vineyard (San Marco, Sicily, 37 $32^{\prime} 5^{\prime \prime}$ $\left.\mathrm{N}, 13^{\circ} 0^{\prime} 2^{\prime \prime} \mathrm{E}\right)$.

Grecanico dorato (syn. Garganega) is an ancient key variety of the Italian grapevine assortment. It is a white, vigorous, medium-late-ripening grapevine cultivar, widely cultivated in western Sicily and in the Venetian area and closely related to the Catarratto Sicilian cultivar. It has a medium, mostly conical bunch and berries with a little pruinose golden-yellow peel $[26,27]$.

Vines were 2.60 by $0.90 \mathrm{~m}$ apart (4273 plants ha ${ }^{-1}$ ), northeast oriented, trellised in a vertical shoot-positioned system, and manually cane-pruned (Guyot system: 8 and 2 buds per cane and spur, respectively). Since its planting, the vineyard was conventionally managed with frequent tillage of inter-row areas and chemical weed control along the vine rows. The year before the beginning of the trial (2009), the farmer began incorporating vine pruning residue in half of the vineyard.

In 2010 and 2011, according to a split-plot experimental design, two nitrogen fertilization levels (fertilized $=\mathrm{F}$ and unfertilized $=\mathrm{UF}$ ) as main plots replicated three times and four soil managements (SMs) randomized in each main plot (winter cover crop (CC), conventional tillage (CT), conventional tillage plus buried vine pruning residue (CT $+\mathrm{PR})$, and winter cover crop plus buried vine pruning residue $(C C+P R)$ ) were established for a total of 24 experimental units. Each experimental unit was represented by four rows, $55 \mathrm{~m}$ long each. In fertilized (F) plots, $92 \mathrm{~kg} \mathrm{ha}^{-1}$ of $\mathrm{N}$ as urea was applied at the beginning of March, during vine dormancy (stage A) [28].

In CT SM, 3-4 tillerings (Tiller spring 7 teeth, Nardi, Perugia, Italy) per year (depending on weed pressure) were done in the inter-row areas at $0.15 \mathrm{~m}$ soil depth, starting after the first rain in autumn.

In both years, Vicia faba L. (wild races), as winter cover crop species, was seeded using a combined power harrow with a mechanical seed drill (Vitigreen 1500, Maschio Gaspardo, Padova, Italy) (CC and CC + PR) in late October in all vineyard inter-row areas at a seeding rate of $80 \mathrm{~kg} \mathrm{ha}^{-1}, 20 \mathrm{~cm}$ row spacing, and $5 \mathrm{~cm}$ depth.

In the SMs that included incorporation of cover crop biomass and vine winter pruning residue (after mechanical shredding), these were mechanically buried by plowing into the soil at a $20 \mathrm{~cm}$ depth in spring (mid-April); otherwise pruning residues were removed from the vineyard.

In all experimental units, one application of chemical weed control (RoundUp UltraMAX, Monsanto Company, St. Louis, MI, USA; glyphosate, a.i. at $3 \mathrm{~kg} \mathrm{ha}^{-1}$ ) under the rows was performed in spring, after the pruning residue and the cover crop biomass burial date. The experimental units in the second year were in the same plots as in the first year.

\subsection{Soil and Cover Crop Biomass Sampling and Analysis}

Soil samples (0-20 and 20-40 cm depth) were collected monthly from February 2009 to December 2011 in the central inter-row areas of each experimental unit. Samples were airdried and passed through a $2 \mathrm{~mm}$ sieve. The soil nitrate $\left(\mathrm{NO}_{3}-\mathrm{N}\right)$ content was determined by aqueous extraction with a Dionex DX120 ion chromatograph (Dionex Corporation, Sunnyvale, CA, USA). Before incorporation, cover crop biomass samples, collected from three different sampling areas $\left(1 \mathrm{~m}^{2}\right.$ each) for each experimental unit, were dried in an oven at $60^{\circ} \mathrm{C}$ until constant weight and then finely ground and analyzed for total $\mathrm{N}$, according to the Kjeldahl method [29].

\subsection{Vineyard Sampling and Analysis}

From each experimental unit, 15 vines $(15 \times 24=360)$ were randomly selected for vine phenology, grape yield, vegetative parameters, and must quality measurements. All the measurements were conducted in the two middle rows of each experimental unit. 


\subsubsection{Phenology}

The occurrence of the main phenological phases-bud break (stage $B=50 \%$ of open buds), berry set (stage J), veraison (stage $\mathrm{M}=10-50 \%$ of softer-colored berries), and ripeness (stage N) dates-were recorded in 2010 and 2011 [28]. To define harvest time (stage N), total soluble solids (TSS) and titratable acidity (TA) were periodically determined on 200 berries randomly collected (weekly after veraison and every 4 days from one month after veraison onward) from different bunch sides (external and internal) and portions (top, middle, and bottom). In both years, grapes were hand-harvested on September 12 when TSS did not increase for two subsequent measurements and TA was not lower than $5 \mathrm{~g} \mathrm{~L}^{-1}$ [30].

\subsubsection{Grape Yield, Vegetative Parameters, and Must Quality}

Bud fruitfulness (number of inflorescence primordia per mature latent bud), bunch weight, and vine yield were determined at harvest time on 15 vines per experimental unit. Yield per hectare was calculated by multiplying yield per vine by the number of vines per hectare (data not shown). Total soluble solids ( ${ }^{\circ}$ Brix) were measured in $1 \mathrm{~kg}$ grape samples per experimental unit using an Atago PR-32 digital refractometer (Atago, Tokyo, Japan). Titratable acidity (TA) was measured in the same samples using a Crison Compact Titrator (Crison Instruments, Barcelona, Spain) by titration $(0.1 \mathrm{~N} \mathrm{NaOH})$ to $\mathrm{pH} 7$ (expressed in $\mathrm{g} \mathrm{L}^{-1}$ of tartaric acid). The pruning fresh weight was determined in winter by collecting all pruned material per plant on 15 vines per experimental unit. The Ravaz index (grape yield per plant to pruning fresh weight ratio $\left(\mathrm{kg} \mathrm{kg}^{-1}\right)$ ) was, therefore, calculated for each experimental unit [31] At harvest time (on grape and leaves) and at winter pruning time (on wood), 15 shoots from different cane portions of 15 vines ( 5 basal, 5 middle, and 5 apical) per experimental unit were collected to evaluate the total dry matter content of grapes, shoots, and leaves $\left(\mathrm{DW}_{\mathrm{gsl}}\right)$ oven-dried at $70{ }^{\circ} \mathrm{C}$ until constant weight. The amount of yeast available nitrogen (YAN) in the must was determined by formol titration. In brief, $50 \mathrm{~mL}$ of non-sulfited must was brought to $\mathrm{pH} 8.5$ by adding $1 \mathrm{M} \mathrm{NaOH}$ and, subsequently, $20 \mathrm{~mL}$ of formic aldehyde. Following the addition of formic aldehyde, and subsequent $\mathrm{pH}$ lowering, the solution was then titrated up to $\mathrm{pH} 8.5$ with $0.1 \mathrm{M} \mathrm{NaOH}$. The volume of $0.1 \mathrm{M} \mathrm{NaOH}$ used for the titration, expressed in milliliters multiplied by 28 , returns the amount of YAN in $\mathrm{mg} \mathrm{L}^{-1}$ [32].

\subsubsection{Soil Nitrogen Inputs and Vine Nitrogen Content Estimation}

In addition to $\mathrm{N}$ supplied by fertilization, soil $\mathrm{N}$ inputs were calculated for each experimental unit as a two-year average of cover crop dry biomass $\left(\left(6.6 \mathrm{t} \mathrm{ha}^{-1} \pm 2.1\right) \times \mathrm{N}\right.$ content $(1.12 \%))$ and pruning residue dry biomass $\left(\left(2.3 \mathrm{tha}^{-1} \pm 0.15\right) \times \mathrm{N}\right.$ content $\left.(0.43 \%)\right)$.

The vine aerial $\mathrm{N}$ content was estimated by multiplying the total biomass of grapes, shoots, and leaves for a variable increasing coefficient (from 0.26 to 0.38 ) inversely related to the grape yield level (from 20 to $7.5 \mathrm{t} \mathrm{ha}^{-1}$ ), according to Bavaresco [33] and Palliotti et al. [34]. The total $\mathrm{N}$ content, partitioned per vine phenological stage, was estimated according to Conradie $[35,36]$.

\subsection{Statistical Analysis}

Data analysis was conducted using the SPSS statistical package [37]. Analysis of variance was carried out according to a split-plot experimental design with fertilization (F) as the main plot. The soil nitrate content was also compared using repeated-measures ANOVA over time. For the productive, vegetative, and qualitative parameters, a three-way analysis of variance was carried out according to the experimental design. A two-way analysis of variance was performed for YAN values detected in the must in 2011. All factors were considered as fixed effect. F- and $p$-values of Fisher tests were reported. Then, Tukey's tests at $p \leq 0.05$ and $p \leq 0.01$ were performed when the main sources of variation and interactions were significant in analysis of variance (ANOVA). 


\section{Results}

\subsection{Rainfall and Temperature Data}

In 2009, the annual rainfall (657.2 $\mathrm{mm})$ was higher compared to $2010(496.7 \mathrm{~mm})$ and $2011(492.7 \mathrm{~mm})$, particularly in the first quarter of the year (281.4 mm vs. 182.2 and 199.5, in 2010 and 2011, respectively) and in the third ( $80.8 \mathrm{~mm}$ vs. 63.5 and 18.2, respectively), whereas in the fourth quarter, a similar precipitation occurred in the 2009-2011 period $(214.9,211.5$, and $207 \mathrm{~mm}$, respectively). The average annual temperature was very similar among years (about $19^{\circ} \mathrm{C}$ ). In 2009, the first quarter was relatively colder than in 2010 and 2011 but warmer in the remaining quarters. The coldest months were February in $2009\left(10.6^{\circ} \mathrm{C}\right)$ and $2011\left(11.1^{\circ} \mathrm{C}\right)$ and January in $2010\left(12.3^{\circ} \mathrm{C}\right)$, whereas the hottest ones were August in $2009\left(28.1^{\circ} \mathrm{C}\right)$ and July in 2010 and $2011\left(27.5^{\circ} \mathrm{C}\right.$ and $27^{\circ} \mathrm{C}$, respectively). The average (1969-2019) climatic characteristics of the experimental area are reported in Figure 1. In summary, all three years considered were hotter than the average but, except 2009, less rainy (Supplementary Material, Table S1).

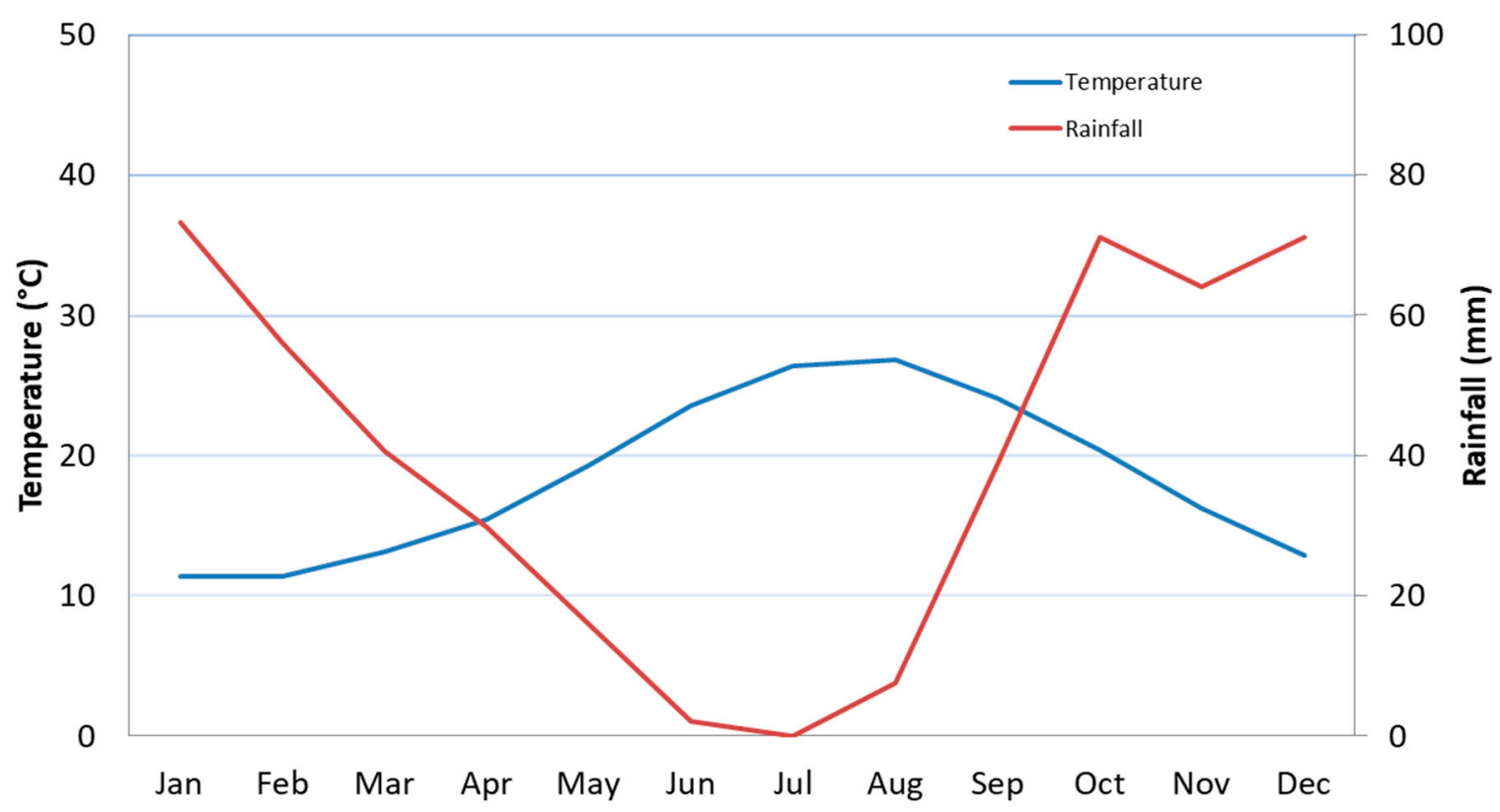

Figure 1. Mean daily temperature and total monthly precipitation (1969-2019) at San Marco, Sicily (37.325 N, 13.002 E). The mean daily temperature and total monthly rainfall (2009-2011) can be found in Supplementary Material Table S1.

\subsection{Nitrogen Input and Soil Nitrate Evolution}

The N inputs (Figure 2) reflect the experimental conditions adopted in the trial between the two main plots ( $\mathrm{F}$ and UF). The average ( 2 years) $\mathrm{N}$ input value provided by urea was $92 \mathrm{~kg} \mathrm{ha}^{-1} \mathrm{yr}^{-1}$, while no urea was applied to UF plots. Nitrogen input provided by the cover crop biomass was higher (about double) in F than in UF CC SM, but only slight differences in $\mathrm{N}$ input due to the CC contribution between $\mathrm{F}$ and UF plots were observed for CC + PR SM. As a whole, the total N input from CC + PR in F plots was about 1.1-fold greater than from CC + PR in UF plots (Figure 2). 


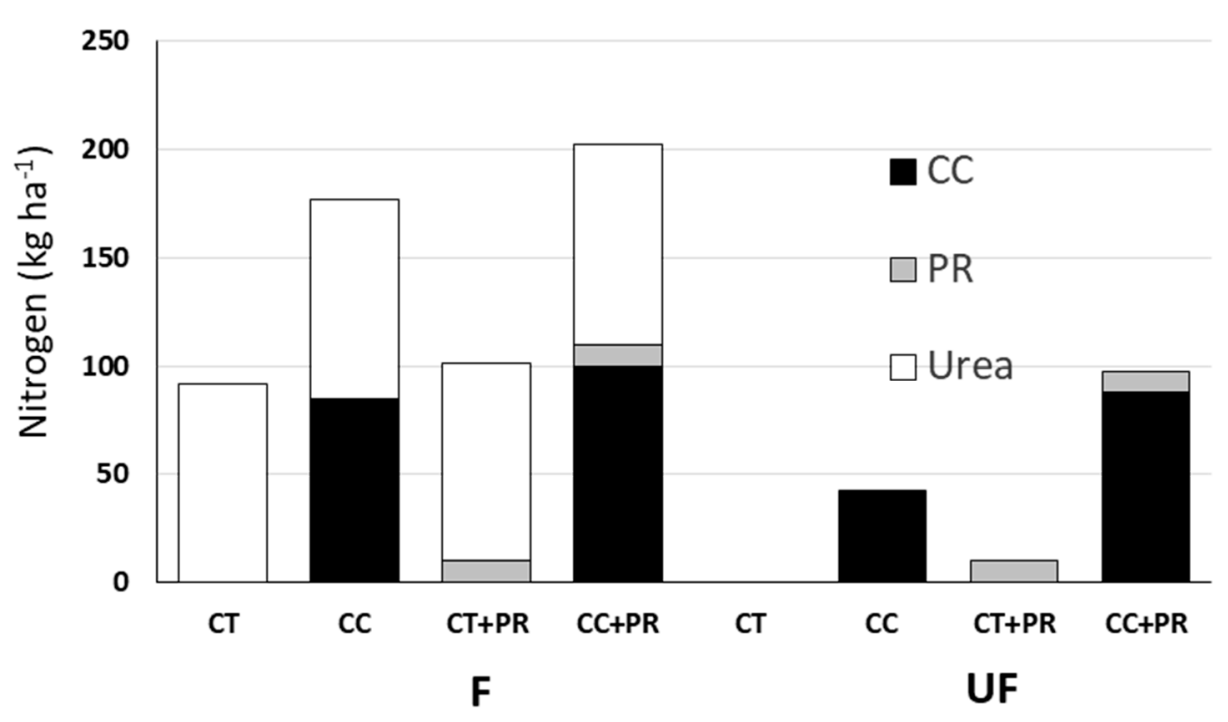

Figure 2. Nitrogen inputs $\left(\mathrm{kg} \mathrm{ha}^{-1}\right)$, as provided by urea (200 $\mathrm{kg} \mathrm{ha}^{-1}$, white histograms) and by cover crop biomass (black histograms) and vine pruning residue (gray histograms) incorporation. On the left, urea-fertilized (F) plots; on the right, unfertilized (UF) plots. Data are the average of two years. Standard deviation values are reported in Supplementary Material Table S2. Soil management $(x$ axis): $\mathrm{CT}=$ conventional tillage; $\mathrm{CC}=$ cover crop; $\mathrm{CT}+\mathrm{PR}=$ conventional tillage plus pruning residue; $C C+P R=$ cover crop plus pruning residue.

Analysis of variance between subjects (Table 1$)$ showed a significant $(p<0.0001)$ effect of fertilization (F) and cover crop (CC) on the average soil nitrate content, as well as their interaction. On the contrary, pruning residue alone or in interaction with other factors had no effect on soil nitrate. Soil nitrate was impacted by all main factors and their interactions in repeated-measures analysis (Table 2).

Table 1. Between-subject ANOVA for soil nitrate $\left(\mathrm{NO}_{3}-\mathrm{N}\right)$ content (Fisher test $\mathrm{F}$ - and $p$-values) in 2010-2011.

\begin{tabular}{ccc}
\hline Source of Variation & F & $p$ \\
\hline Fertilization (F) & 269.63 & $<0.0001$ \\
Pruning residue (PR) & 0.12 & 0.7349 \\
Cover crop (CC) & 83.13 & $<0.0001$ \\
F $\times$ PR & 3.57 & 0.0915 \\
F $\times$ CC & 26.3 & $<0.0001$ \\
PR $\times$ CC & 0.98 & 0.9721 \\
F $\times$ PR $\times$ CC & 2.71 & 0.1083 \\
\hline
\end{tabular}

Table 2. Within-subject ANOVA for soil nitrate $\left(\mathrm{NO}_{3}-\mathrm{N}\right)$ content (Fisher test $\mathrm{F}$ - and $p$-values) in 2010-2011.

\begin{tabular}{ccc}
\hline Source of Variation & F & $p$ \\
\hline Soil sampling time $(\mathrm{T})$ & 157.13 & $<0.0001$ \\
$\mathrm{~T} \times$ Fertilization $(\mathrm{F})$ & 26.96 & $<0.0001$ \\
$\mathrm{~T} \times$ Pruning residue $(\mathrm{PR})$ & 3.72 & $<0.0001$ \\
$\mathrm{~T} \times$ Cover crop $(\mathrm{CC})$ & 33.06 & $<0.0001$ \\
$\mathrm{~T} \times \mathrm{F} \times \mathrm{PR}$ & 6.58 & $<0.0001$ \\
$\mathrm{~T} \times \mathrm{F} \times \mathrm{CC}$ & 7.45 & $<0.0001$ \\
$\mathrm{~T} \times \mathrm{PR} \times \mathrm{CC}$ & 3.52 & $<0.0001$ \\
$\mathrm{~T} \times \mathrm{F} \times \mathrm{PR} \times \mathrm{CC}$ & 1.55 & 0.0292 \\
\hline
\end{tabular}


Evolution of the soil $\mathrm{NO}_{3}-\mathrm{N}$ content, at $0-40 \mathrm{~cm}$ soil depth, in $\mathrm{CT}, \mathrm{CC}, \mathrm{CT}+\mathrm{PR}$, and CC + PR SMs is reported in Figures 3 and 4, for F and UF plots, respectively. The initial $\mathrm{NO}_{3}-\mathrm{N}$ content (year 2009) was monitored before trial establishment for only two SM systems (CT and CT + PR in F and UF plots) adopted in the vineyard at that time (Figures 3 and 4).

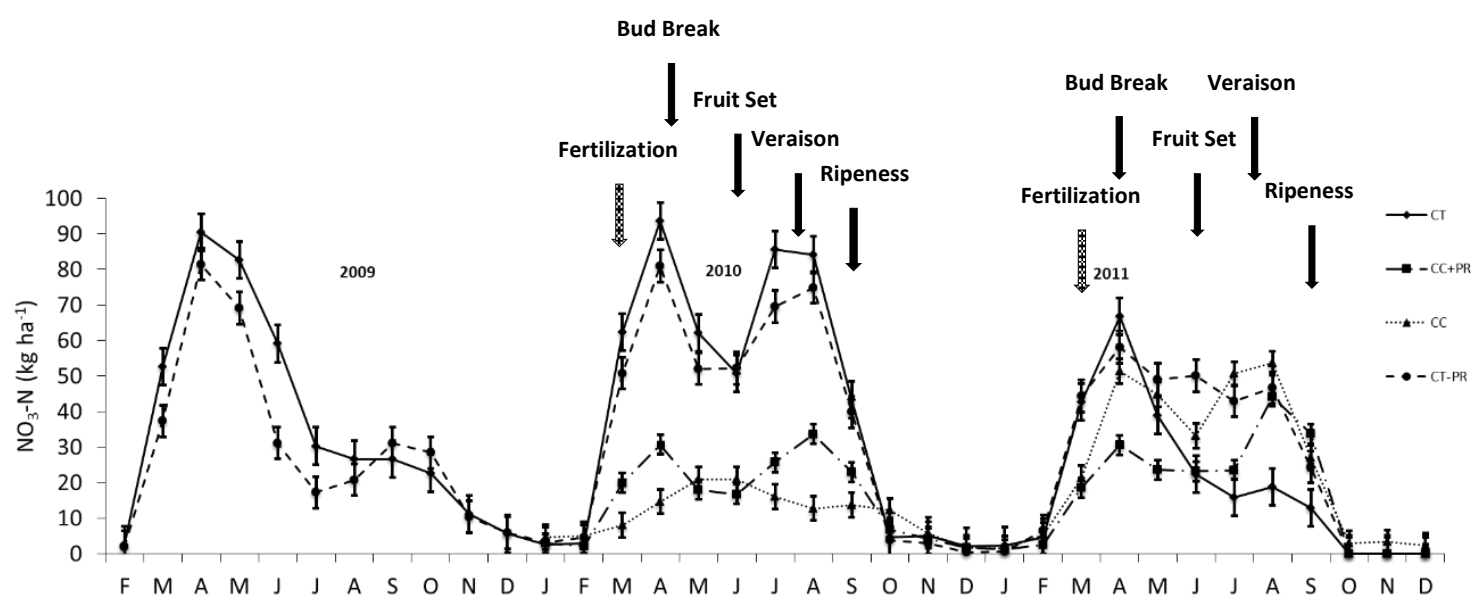

Figure 3. Evolution of soil nitrate $\left(\mathrm{NO}_{3}-\mathrm{N}\right)$ content $\left(\mathrm{kg} \mathrm{ha}^{-1}\right)$ in $0-40 \mathrm{~cm}$ soil depth in urea $\left(200 \mathrm{~kg} \mathrm{ha}^{-1}\right)$-fertilized $(\mathrm{F})$ plots in the 2009-2011 period. Soil management: $C T$, conventional tillage; $C C=$ cover crop; $C T+P R=$ conventional tillage plus pruning residue; $\mathrm{CC}+\mathrm{PR}=$ cover crop plus pruning residue. Bars indicate standard deviation $(n=3)$.

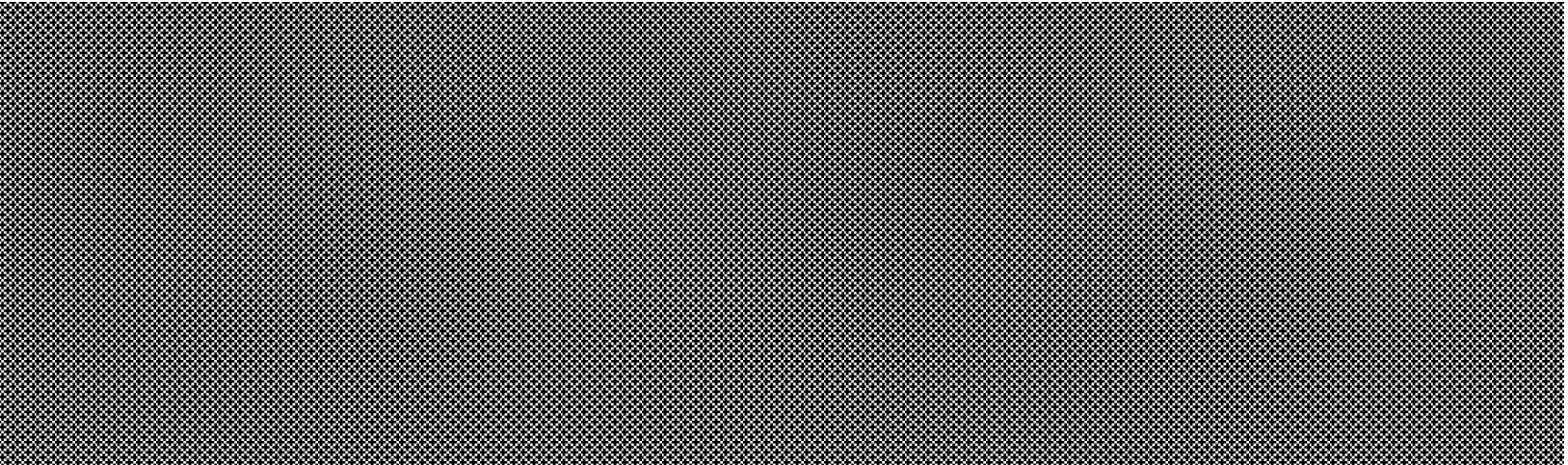

Figure 4. Evolution of soil nitrate $\left(\mathrm{NO}_{3}-\mathrm{N}\right)$ content $\left(\mathrm{kg} \mathrm{ha}^{-1}\right)$ in $0-40 \mathrm{~cm}$ soil depth in unfertilized (UF) plots in the $2009-2011$ period. Soil management: $\mathrm{CT}=$ conventional tillage; $\mathrm{CC}=$ cover crop; $\mathrm{CT}+\mathrm{PR}=$ conventional tillage plus pruning residue; $\mathrm{CC}+\mathrm{PR}=$ cover crop plus pruning residue. Bars indicate standard deviation $(n=3)$.

In F plots, during the entire period of observation, an initial rapid and intense rise in the level of $\mathrm{NO}_{3}-\mathrm{N}$ could be observed at the beginning of March, i.e., after urea fertilization (Figure 3). During the first year of the trial (2010), CT and CT + PR had a similar trend, showing absolute highest values of $\mathrm{NO}_{3}-\mathrm{N}$ content (Figure 3). In 2011, CT and CT + PR had lower $\mathrm{NO}_{3}-\mathrm{N}$ than in 2010, whereas $\mathrm{CC}$ had higher $\mathrm{NO}_{3}-\mathrm{N}$ at most sampling times. Moreover, in F plots (Figure 3) and in both years, soil $\mathrm{NO}_{3}-\mathrm{N}$ availability was generally higher for all experimental units from April to August, i.e., from vine bud break to veraison, with an inflection at the time of fruit set (early June), while it strongly decreased in autumn and winter.

In UF plots (Figure 4), as expected, soil $\mathrm{NO}_{3}-\mathrm{N}$ was generally much lower than in $\mathrm{F}$ plots. In 2010, the highest values of soil $\mathrm{NO}_{3}-\mathrm{N}$ were observed in $\mathrm{CT}$ and $\mathrm{CT}+\mathrm{PR}$, while in 2011, the highest values were recorded in CC + PR. Similarly to F plots, the highest values were recorded in April and August and the lowest ones were recorded in autumn and winter. The maximum $\mathrm{NO}_{3}-\mathrm{N}$ in UF plots (in $\mathrm{CT}$ and $\mathrm{CT}+\mathrm{PR}$ ) were about one-third of the corresponding maximum $\mathrm{NO}_{3}-\mathrm{N}$ in F plots. 


\subsection{Grapevine Phenology}

The phenological development of the Grecanico dorato grapevine in 2010 and 2011 showed only slight, not significant differences between the two years. In 2011, somewhat earlier bud break (-6 days) and ripening (-4 days) were observed compared to 2010. As a whole, no phenological difference was found among the vines under different soil management and fertilization conditions, except for an observed slight, later bud break (+3 days) in 2011 in CT + PR and CC + PR in fertilized vines compared to CT and CC (data not reported).

\subsection{Vine Vegetative Growth, Yield, and Must Quality}

The analysis of variance performed on vine vegetative and productive parameters (Table 3) showed that the main source of variation, year, had a significant effect on fruitfulness, grape yield, $\mathrm{DW}_{\mathrm{gsl}}$, and Ravaz index, while soil management had a significant influence on fruitfulness, grape yield, $\mathrm{DW}_{\mathrm{gsl}}$, and sugar content. Finally, fertilization had an effect on fruitfulness and $\mathrm{DW}_{\mathrm{gsl}}$ only. The fertilization $\times$ soil management interaction was significant for almost all considered parameters except for fruitfulness and titratable acidity, while the year $\times$ fertilization $\times$ soil management interaction was significant only for pruning wood weight, $\mathrm{DW}_{\mathrm{gsl}}$, and Ravaz index. The ANOVA for must yeast available $\mathrm{N}$ (YAN) showed the significance of both main factors fertilization and soil management and of their interaction (Table 4). Not surprisingly, $\mathrm{N}$ fertilization is the factor that most influenced the YAN content $(\mathrm{F}=81.6 ; p \leq 0.001)$, followed by soil management. The mean values of YAN for each main source of variation are reported in Table 5. In F vines, YAN was about $13 \%$ greater than in UF ones. Among soil managements, CC and CC + PR showed significantly higher YAN values than CT.

Table 3. Three-way ANOVA in Grecanico dorato vines for yield, vegetative growth, and berry qualitative parameters (Fisher test F- and $p$-values).

\begin{tabular}{|c|c|c|c|c|c|c|c|c|c|c|c|c|c|c|c|c|}
\hline \multirow[t]{2}{*}{$\begin{array}{l}\text { Source of } \\
\text { Variation }\end{array}$} & \multicolumn{2}{|c|}{ Fruitfulness } & \multicolumn{2}{|c|}{ Bunch } & \multicolumn{2}{|c|}{ Yield } & \multicolumn{2}{|c|}{$\begin{array}{l}\text { Pruning } \\
\text { Wood }\end{array}$} & \multicolumn{2}{|c|}{$\mathrm{DW}_{\mathrm{gsl}}{ }^{(w)}$} & \multicolumn{2}{|c|}{$\begin{array}{l}\text { Ravaz } \\
\text { Index }\end{array}$} & \multicolumn{2}{|c|}{ TSS $^{(z)}$} & \multicolumn{2}{|c|}{$\begin{array}{c}\text { Titratable } \\
\text { Acidity }\end{array}$} \\
\hline & $\mathbf{F}$ & $p$ & $\mathbf{F}$ & $p$ & $\mathbf{F}$ & $p$ & $\mathbf{F}$ & $p$ & F & $p$ & $\mathbf{F}$ & $p$ & F & $p$ & $\mathbf{F}$ & $p$ \\
\hline Year $(Y)$ & 1458 & 0.00 & 3.23 & 0.17 & 675 & 0.00 & 3.94 & 0.14 & 379 & 0.00 & 162 & 0.00 & 0.00 & 0.98 & 0.02 & 0.88 \\
\hline Fertilization $(\mathrm{F})$ & 21 & 0.00 & 0.06 & 0.98 & 0.96 & 0.51 & 1.05 & 0.48 & 92 & 0.00 & 3.312 & 0.09 & 0.34 & 0.79 & 0.21 & 0.66 \\
\hline $\begin{array}{l}\text { Soil management } \\
\qquad(\mathrm{SM})\end{array}$ & 62 & 0.00 & 0.94 & 0.40 & 10.50 & 0.04 & 2.07 & 0.25 & 42 & 0.00 & 0.387 & 0.55 & 4.38 & 0.04 & 0.78 & 0.54 \\
\hline $\mathrm{Y} \times \mathrm{F}$ & 0.21 & 0.88 & 0.06 & 0.98 & 0.96 & 0.51 & 3.94 & 0.14 & 1.1 & 0.40 & 2.703 & 0.18 & 0.34 & 0.79 & 0.77 & 0.55 \\
\hline $\mathrm{Y} \times \mathrm{SM}$ & 0.07 & 0.80 & 0.94 & 0.40 & 8.48 & 0.06 & 1.05 & 0.48 & 2.3 & 0.15 & 0.315 & 0.60 & 1.65 & 0.24 & 0.21 & 0.66 \\
\hline $\mathrm{F} \times \mathrm{SM}$ & 2.33 & 0.16 & 11.2 & 0.04 & 25.07 & 0.01 & 9.00 & 0.02 & 8.6 & 0.04 & 3.893 & 0.04 & 4.62 & 0.03 & 0.14 & 0.93 \\
\hline $\mathrm{Y} \times \mathrm{F} \times \mathrm{SM}$ & 0.02 & 0.99 & 1.10 & 0.41 & 0.36 & 0.78 & 11.65 & 0.01 & 16 & 0.00 & 6.130 & 0.02 & 1.09 & 0.40 & 0.17 & 0.91 \\
\hline
\end{tabular}

${ }^{(w)} \mathrm{DW}_{\mathrm{gsl}}$ Grape, shoot, and leaf dry matter per vine; ${ }^{(z)}$ Total Soluble Solid content.

Table 4. Two-way ANOVA in Grecanico dorato vines for must yeast (Fisher test F- and $p$-values).

\begin{tabular}{ccc}
\hline Source of Variation & F & $p$ \\
\hline Fertilization $(\mathrm{F})$ & 81.576 & 0.00 \\
Soil management (SM) & 9.030 & 0.00 \\
F $\times$ SM & 3.904 & 0.03 \\
\hline
\end{tabular}


Table 5. Mean values of Grecanico dorato must yeast available nitrogen (YAN) for each main source of variation.

\begin{tabular}{cc}
\hline Source of Variation & YAN $\left(\mathbf{m g ~ L}^{-\mathbf{1}}\right)$ \\
\hline Fertilization & $325.3^{\mathrm{A}}$ \\
F & $284.1^{\mathrm{B}}$ \\
UF & \\
Soil Management & $288.7^{\mathrm{b}}$ \\
CT & $320.4^{\mathrm{a}}$ \\
CC & $299.1^{\mathrm{a}, \mathrm{b}}$ \\
CT + PR & $310.6^{\mathrm{a}}$ \\
\hline
\end{tabular}

$\mathrm{F}=$ fertilization with urea $\left(200 \mathrm{~kg} \mathrm{ha}^{-1}\right) ; \mathrm{UF}=$ unfertilized. Soil management: $\mathrm{CT}=$ conventional tillage; $\mathrm{CC}=$ cover crop; $\mathrm{CT}+\mathrm{PR}=$ conventional tillage plus pruning residue; $\mathrm{CC}+\mathrm{PR}=$ cover crop plus pruning residue. Different letters denote significant differences at $p \leq 0.05$ (lowercase letters) or $p \leq 0.01$ (capital letters) (Tukey's test).

In Table 6, the mean values of Grecanico dorato vine yield, vegetative growth, and berry qualitative parameters, as affected by each main source of variation, are reported. As a whole, in the second year of study (2011), fruitfulness, yield, DW $\mathrm{gsl}_{\text {, }}$, and Ravaz index significantly ( $p \leq 0.01)$ diminished when compared to 2010. Fertilization significantly $(p \leq 0.01)$ increased fruitfulness and $\mathrm{DW}_{\mathrm{gsl}}$ but did not influence the other parameters. Soil management differently affected fruitfulness, yield, $\mathrm{DW}_{\mathrm{gsl}}$, and TSS. The lowest values of fruitfulness, yield, and $\mathrm{DW}_{\mathrm{gsl}}$, were observed in $\mathrm{CC}$, whereas SMs including pruning residue incorporation (CT + PR and CC + PR) showed the highest values of fruitfulness, yield, and $\mathrm{DW}_{\mathrm{ggl}}$. The highest value of TSS was found in CC + PR. No significant influence of year, fertilization, and soil management was observed on bunch weight, pruning wood fresh weight, and TA, and there was no significant influence of fertilization and soil management on the Ravaz index.

Table 6. Mean values of Grecanico dorato vine yield, vegetative growth, and berry qualitative parameters, as affected by each main source of variation.

\begin{tabular}{|c|c|c|c|c|c|c|c|c|}
\hline $\begin{array}{l}\text { Source of } \\
\text { Variation }\end{array}$ & $\begin{array}{c}\text { Fruitfulness } \\
\text { (No. of Bunches } \\
\text { per Bud) }\end{array}$ & $\begin{array}{c}\text { Bunch } \\
\text { Weight (g) }\end{array}$ & $\begin{array}{c}\text { Yield } \\
\left(\mathrm{kg} \mathrm{Vine}^{-1}\right)\end{array}$ & $\begin{array}{l}\text { Pruning Wood } \\
\text { Fresh Weight } \\
\left.\text { (kg Vine }^{-1}\right)\end{array}$ & $\begin{array}{c}\mathrm{DW}_{\text {gsl }}{ }^{(w)} \\
\left(\mathrm{kg} \mathrm{Vine}^{-1}\right)\end{array}$ & $\begin{array}{c}\text { Ravaz Index } \\
\text { (Yield/Pruning } \\
\text { Wood) }\end{array}$ & $\begin{array}{l}\text { TSS }{ }^{(z)} \\
\left({ }^{\circ} \text { Brix) }\right.\end{array}$ & $\begin{array}{c}\text { Titratable } \\
\text { Acidity } \\
\left(\mathrm{g} \mathrm{L}^{-1}\right)\end{array}$ \\
\hline \multicolumn{9}{|l|}{ Year } \\
\hline 2010 & $1.61^{\mathrm{A}}$ & 286.4 & $4.6^{\mathrm{A}}$ & 1.0 & $1.76^{\mathrm{A}}$ & $4.6^{\mathrm{A}}$ & 19.4 & 5.9 \\
\hline 2011 & $0.99^{\mathrm{B}}$ & $299.4^{\text {n.s. }}$ & $2.9^{\mathrm{B}}$ & $1.1^{\text {n.s. }}$ & $1.38^{\mathrm{B}}$ & $2.7^{\mathrm{B}}$ & $19.4^{\text {n.s. }}$ & $6.0^{\text {n.s. }}$ \\
\hline \multicolumn{9}{|l|}{ Fertilization } \\
\hline $\mathrm{F}$ & $1.34^{\mathrm{A}}$ & 299.3 & 4.0 & 1.1 & $1.67^{\mathrm{A}}$ & 3.7 & 19.4 & 5.9 \\
\hline UF & $1.26^{\mathrm{B}}$ & $286.5^{\text {n.s. }}$ & $3.5^{\text {n.s. }}$ & $1.0^{\text {n.s. }}$ & $1.48^{\mathrm{B}}$ & $3.6^{\text {n.s. }}$ & $19.3^{\text {n.s. }}$ & $6.1^{\text {n.s. }}$ \\
\hline \multicolumn{9}{|l|}{ Soil } \\
\hline Managemen & & & & & & & & \\
\hline $\mathrm{CT}$ & $1.25 \mathrm{AB}$ & 302.3 & $3.7^{\mathrm{A}, \mathrm{B}}$ & 1.0 & $1.52^{\mathrm{A}, \mathrm{B}}$ & 3.8 & $19.4^{\mathrm{b}}$ & 5.7 \\
\hline $\mathrm{CC}$ & $1.15^{\mathrm{B}}$ & 283.3 & $3.2^{\mathrm{B}}$ & 1.0 & $1.42^{\mathrm{B}}$ & 3.2 & $19.2^{b}$ & 6.0 \\
\hline $\mathrm{CT}+\mathrm{PR}$ & $1.35^{\mathrm{A}}$ & 301.5 & $4.0^{\mathrm{A}}$ & 1.1 & $1.65^{\mathrm{A}}$ & 3.8 & $18.6^{c}$ & 6.1 \\
\hline $\mathrm{CC}+\mathrm{PR}$ & $1.45^{\mathrm{A}}$ & $284.5^{\text {n.s. }}$ & $4.1^{\mathrm{A}}$ & $1.1^{\text {n.s. }}$ & $1.70^{\mathrm{A}}$ & $3.7^{\text {n.s. }}$ & $20.4^{\mathrm{a}}$ & $6.0^{\text {n.s. }}$ \\
\hline
\end{tabular}

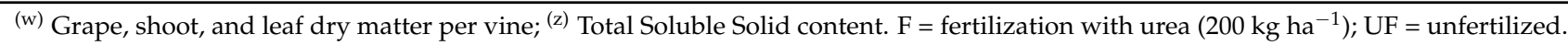
Soil management: $\mathrm{CT}=$ conventional tillage $\mathrm{CC}=$ cover crop; $\mathrm{CT}+\mathrm{PR}=$ conventional tillage plus pruning residue; $\mathrm{CC}+\mathrm{PR}=\mathrm{cover}$ crop plus pruning residue. Different letters denote significant differences at $p \leq 0.05$ (lowercase letters) or $p \leq 0.01$ (capital letters) (Tukey's test); n.s. = not significant.

Looking at the effects of the interaction between fertilization and soil management (Table 7), the highest values of bunch weight, yield, $\mathrm{DW}_{\mathrm{gsl}}$, and Ravaz index and the lowest values of TSS were observed in F plots in vines where CT + PR was applied. On the contrary, in both F and UF vines, the lowest values of yield and Ravaz index were obtained in vines managed with cover crop (CC). In F vines, the highest vigor (pruning weight) and must sugar content (TSS) values were observed with CC + PR and the highest YAN 
with CC, even if not significantly different from the other soil managements (CT, CT + PR, and CC + PR). In UF vines, CC + PR displayed the highest values of yield, Ravaz index, and TSS, whereas CC, together with the lowest yield, showed the highest value of bunch weight (Table 7). Altogether, $\mathrm{F}$ vines yielded about half a kilogram of grape per vine (i.e., $2 \mathrm{t} \mathrm{ha}^{-1}$ ) more than UF vines. As already evidenced (Table 5), the must YAN values were significantly higher in $\mathrm{F}$ than in UF plots and, as a whole, ranged between a minimum of 255.1 (UF-CT) and a maximum of $334.1 \mathrm{mg} \mathrm{L}^{-1}$ (F-CC). In the must of UF vines, YAN was clearly improved by cover cropping and the burying of pruning residue (CC and CC + PR) compared to CT (Table 7).

Table 7. Mean values of Grecanico dorato vine yield, vegetative growth, and qualitative parameters, as affected by the interaction between fertilization and soil management.

\begin{tabular}{|c|c|c|c|c|c|c|c|}
\hline $\begin{array}{l}\text { Fertilization } \times \text { Soil } \\
\text { Management }\end{array}$ & $\begin{array}{l}\text { Bunch } \\
\text { Weight } \\
\text { (g) }\end{array}$ & $\begin{array}{c}\text { Yield } \\
\left(\mathrm{kg} \mathrm{Vine}^{-1}\right)\end{array}$ & $\begin{array}{l}\text { Pruning Wood } \\
\text { Fresh Weight } \\
\left.\text { (kg Vine }^{-1}\right)\end{array}$ & $\underset{\left(\mathrm{kg} \mathrm{Vine}^{-1}\right)}{\mathrm{DW}_{\mathrm{gsl}}{ }^{(w)}}$ & $\begin{array}{c}\text { Ravaz Index } \\
\text { (Yield/Pruning Wood) }\end{array}$ & $\begin{array}{l}\text { TSS }{ }^{(z)} \\
\left({ }^{\circ} \text { Brix) }\right.\end{array}$ & $\begin{array}{l}\mathrm{YAN}^{(x)} \\
\left(\mathrm{mg} \mathrm{L}^{-1}\right)\end{array}$ \\
\hline \multicolumn{8}{|l|}{$\mathrm{F}$} \\
\hline $\mathrm{CT}$ & $319.0^{\mathrm{a}}$ & $4.1^{\mathrm{b}}$ & $1.0^{\mathrm{b}}$ & $1.64^{\mathrm{a}, \mathrm{b}}$ & $4.0^{\mathrm{a}}$ & $20.0^{a}$ & $322.5^{\mathrm{a}}$ \\
\hline $\mathrm{CC}$ & $260.5^{b}$ & $3.2^{c}$ & $1.0^{\mathrm{b}}$ & $1.43^{b}$ & $3.0^{b}$ & $18.5^{b}$ & $334.1^{\mathrm{a}}$ \\
\hline $\mathrm{CT}+\mathrm{PR}$ & $335.0^{a}$ & $4.7^{\mathrm{a}}$ & $1.1^{\mathrm{a}, \mathrm{b}}$ & $1.84^{\mathrm{a}}$ & $4.3^{\mathrm{a}}$ & $18.5^{\mathrm{b}}$ & $318.5^{\mathrm{a}}$ \\
\hline $\mathrm{CC}+\mathrm{PR}$ & $282.5^{b}$ & $4.0^{b}$ & $1.2^{\mathrm{a}}$ & $1.77^{\mathrm{a}}$ & $3.4^{b}$ & $20.6^{a}$ & $326.2^{\mathrm{a}}$ \\
\hline \multicolumn{8}{|l|}{ UF } \\
\hline $\mathrm{CT}$ & $285.5^{b}$ & $3.3^{c}$ & $0.9^{b}$ & $1.41^{\mathrm{b}}$ & $3.5^{b}$ & $18.8^{b}$ & $255.1^{c}$ \\
\hline $\mathrm{CC}$ & $306.0^{a}$ & $3.3^{c}$ & $1.0^{\mathrm{b}}$ & $1.42^{b}$ & $3.4^{b}$ & $19.8^{a}$ & $306.6^{b}$ \\
\hline $\mathrm{CT}+\mathrm{PR}$ & $268.0^{b}$ & $3.4^{c}$ & $1.0^{\mathrm{b}}$ & $1.47^{\mathrm{b}}$ & $3.4^{\mathrm{b}}$ & $18.7^{\mathrm{b}}$ & $279.7^{\mathrm{b}, \mathrm{c}}$ \\
\hline $\mathrm{CC}+\mathrm{PR}$ & $286.5^{\mathrm{b}}$ & $4.1^{\mathrm{b}}$ & $1.0^{\mathrm{b}}$ & $1.64^{\mathrm{ab}}$ & $4.0^{\mathrm{a}}$ & $20.1^{\mathrm{a}}$ & $294.9^{b}$ \\
\hline
\end{tabular}

(w) Grape, wood, and leaf dry matter per vine; (z) Total Soluble Solid content; ${ }^{(x)}$ Yeast Available Nitrogen. F = fertilization with urea (200 $\left.\mathrm{kg} \mathrm{ha}^{-1}\right) ; \mathrm{UF}=$ unfertilized. Soil management: $\mathrm{CT}=$ conventional tillage; $\mathrm{CC}=$ cover crop; $\mathrm{CT}+\mathrm{PR}=\mathrm{conventional}$ tillage plus pruning residue; $\mathrm{CC}+\mathrm{PR}=$ cover crop plus pruning residue. Different letters denote significant differences at $p \leq 0.05$ (Tukey's test).

In both years, the values of $\mathrm{DW}_{\mathrm{gsl}}$ were the highest in $\mathrm{F}$ vines grown in $\mathrm{CT}+\mathrm{PR}$ and $\mathrm{CC}+\mathrm{PR}$ (i.e., about $1.8 \mathrm{~kg}$ of grape, shoot, and leaf dry matter per vine in F vs. $1.55 \mathrm{~kg}$, on average, in UF) (Table 8). In F plots, comparing the pruning wood weight values attained in CT + PR and CC + PR between 2010 and 2011, an increased average vigor of these vines of about $20 \%$ could be observed in the second year of study ( $1.07 \mathrm{vs} .1 .29 \mathrm{~kg}$ per vine), in spite of an average lower $\mathrm{DW}_{\mathrm{gsl}}$ (1.98 and $1.63 \mathrm{~kg}$ per vine in 2010 and 2011, respectively). On the contrary, the vigor of UF vines, as indicated by pruning weight, was very similar between the years and among the SMs. On the whole, UF pruning wood weight was about $11 \%$ less than in F vines. The Ravaz index was higher in F than in UF plots in 2010 (on average 4.7 and 4.4, respectively) but very similar in 2011 and, in any case, constantly lower (almost halved) than in 2010. However, the same, absolute highest value (5.0) was recorded both in F-CT plots and in UF-CC + PR plots in 2010. In 2011, the highest value of the Ravaz index (3.1) was recorded for CC + PR.

\subsection{Vine Nitrogen Content}

Fertilization with urea $\left(200 \mathrm{~kg} \mathrm{ha}^{-1}\right)$ had a poor effect on the amount of total $\mathrm{N}$ accumulated in the aerial biomass (grapes, shoots, leaves) in both years (Table 9). However, in 2011, a generalized reduction (about 15\% less) of $\mathrm{N}$ content could be observed for all soil managements and in both plots (F and UF) compared to 2010. On average, vines in $\mathrm{CT}+\mathrm{PR}$ and $\mathrm{CC}+\mathrm{PR}$ had the highest $\mathrm{N}$ content in both F and UF plots, whereas the lowest $\mathrm{N}$ content was recorded for $\mathrm{CC}$. In UF vines, $\mathrm{CC}+\mathrm{PR}$ had the highest values of $\mathrm{N}$ accumulated in all phenological phases in both years (Table 9). 
Table 8. Mean values of Grecanico dorato vine pruning wood, dry mass, and Ravaz index, as affected by the interactions among year, fertilization, and soil management.

\begin{tabular}{|c|c|c|c|c|c|c|}
\hline \multirow[b]{2}{*}{$\begin{array}{c}\text { Fertilization } \times \\
\text { Soil } \\
\text { Management }\end{array}$} & \multicolumn{3}{|c|}{2010} & \multicolumn{3}{|c|}{2011} \\
\hline & $\begin{array}{l}\text { Pruning Wood } \\
\text { Fresh Weight } \\
\left.\text { (kg Vine }^{-1}\right)\end{array}$ & $\begin{array}{c}\mathrm{DW}_{\mathrm{gsl}}{ }^{(\mathrm{z})} \\
\left(\mathrm{kg} \text { Vine }^{-1}\right)\end{array}$ & $\begin{array}{c}\text { Ravaz Index } \\
\text { (Yield/Pruning } \\
\text { Wood) }\end{array}$ & $\begin{array}{l}\text { Pruning Wood } \\
\text { Fresh Weight } \\
\left.\text { (kg Vine }^{-1}\right)\end{array}$ & $\begin{array}{c}\mathrm{DW}_{\mathrm{gsl}}{ }^{(\mathrm{z})} \\
\left(\mathrm{kg} \text { Vine }^{-1}\right)\end{array}$ & $\begin{array}{c}\text { Ravaz Index } \\
\text { (Yield/Pruning } \\
\text { Wood) }\end{array}$ \\
\hline \multicolumn{7}{|l|}{$\mathrm{F}$} \\
\hline $\mathrm{CT}$ & 1.01 & $1.86^{\mathrm{a}, \mathrm{b}}$ & $5.0^{\mathrm{a}}$ & $1.04^{b}$ & $1.42^{b}$ & $3.0^{\mathrm{a}}$ \\
\hline CC & 1.05 & $1.65^{\mathrm{b}}$ & $3.8^{b}$ & $1.02^{\mathrm{b}}$ & $1.20^{\mathrm{c}}$ & $2.2^{\mathrm{c}}$ \\
\hline $\mathrm{CT}+\mathrm{PR}$ & 1.02 & $2.04^{\mathrm{a}}$ & $5.6^{\mathrm{a}}$ & $1.23^{\mathrm{a}}$ & $1.65^{\mathrm{a}}$ & $2.9^{a}$ \\
\hline $\mathrm{CC}+\mathrm{PR}$ & $1.12^{\text {n.s. }}$ & $1.93^{\mathrm{a}}$ & $4.5^{b}$ & $1.35^{\mathrm{a}}$ & $1.61^{\mathrm{a}}$ & $2.3^{c}$ \\
\hline \multicolumn{7}{|l|}{ UF } \\
\hline $\mathrm{CT}$ & 0.94 & $1.59^{b}$ & $4.3^{b}$ & $0.95^{b}$ & $1.23^{c}$ & $2.7^{\mathrm{b}}$ \\
\hline $\mathrm{CC}$ & 0.96 & $1.58^{\mathrm{b}}$ & $4.2^{b}$ & $0.98^{b}$ & $1.26^{\mathrm{c}}$ & $2.7^{b}$ \\
\hline $\mathrm{CT}+\mathrm{PR}$ & 1.00 & $1.63^{b}$ & $4.1^{b}$ & $1.03^{b}$ & $1.31^{b c}$ & $2.6^{b}$ \\
\hline $\mathrm{CC}+\mathrm{PR}$ & $1.01^{\text {n.s. }}$ & $1.85^{\mathrm{a}, \mathrm{b}}$ & $5.0^{\mathrm{a}}$ & $1.02^{b}$ & $1.42^{b}$ & $3.1^{\mathrm{a}}$ \\
\hline
\end{tabular}

(Z) Grape, shoot, and leaf dry matter per vine. $\mathrm{F}=$ fertilization with urea $\left(200 \mathrm{~kg} \mathrm{ha}^{-1}\right)$; UF $=$ unfertilized. Soil management: $\mathrm{CT}=$ conventional tillage; $\mathrm{CC}=$ cover crop; $\mathrm{CT}+\mathrm{PR}=$ conventional tillage plus pruning residue; $\mathrm{CC}+\mathrm{PR}=$ cover crop plus pruning residue. Different letters denote significant differences at $p \leq 0.05$ (Tukey's test); n.s. $=$ not significant.

Table 9. Estimated amount of nitrogen $\left(\mathrm{kg} \mathrm{ha}^{-1}\right)$ in the aerial biomass (grapes, shoots, leaves) of Grecanico dorato vines during different phenological stages in two years (2010 and 2011), as affected by fertilization and different soil managements.

\begin{tabular}{|c|c|c|c|c|c|c|c|c|}
\hline & \multicolumn{7}{|c|}{ Phenological Stage } & \multirow[b]{2}{*}{ Total } \\
\hline & Fruit Set & Veraison & Harvest & Total & Fruit Set & Veraison & Harvest & \\
\hline $\begin{array}{l}\text { Fertilization } \times \text { Soil } \\
\text { Management }\end{array}$ & & \multicolumn{2}{|c|}{2010} & \multicolumn{5}{|c|}{2011} \\
\hline \multicolumn{9}{|l|}{$F$} \\
\hline $\mathrm{CT}$ & 18.5 & 25.1 & 22.5 & 66.1 & 16.3 & 22.1 & 19.8 & 58.1 \\
\hline $\mathrm{CC}$ & 17.4 & 23.6 & 21.1 & 62.2 & 14.8 & 20.0 & 17.9 & 52.7 \\
\hline $\mathrm{CT}+\mathrm{PR}$ & 20.7 & 28.1 & 25.1 & 74.0 & 17.0 & 23.0 & 20.6 & 60.6 \\
\hline $\mathrm{CC}+\mathrm{PR}$ & 19.5 & 26.5 & 23.7 & 69.7 & 17.2 & 23.4 & 20.9 & 61.5 \\
\hline \multicolumn{9}{|l|}{ UF } \\
\hline $\mathrm{CT}$ & 17.2 & 23.3 & 20.9 & 61.4 & 14.5 & 19.6 & 17.6 & 51.7 \\
\hline $\mathrm{CC}$ & 17.0 & 23.0 & 20.6 & 60.6 & 14.8 & 20.1 & 18.0 & 52.8 \\
\hline $\mathrm{CT}+\mathrm{PR}$ & 17.4 & 23.7 & 21.2 & 62.3 & 15.3 & 20.7 & 18.6 & 54.6 \\
\hline $\mathrm{CC}+\mathrm{PR}$ & 19.2 & 26.0 & 23.3 & 68.4 & 16.3 & 22.1 & 19.8 & 58.1 \\
\hline
\end{tabular}

$\mathrm{F}=$ fertilization with urea $\left(200 \mathrm{~kg} \mathrm{ha}^{-1}\right) ; \mathrm{UF}=$ unfertilized. Soil management: $\mathrm{CT}=$ conventional tillage; $\mathrm{CC}=$ cover crop; $\mathrm{CT}+\mathrm{PR}=$ conventional tillage plus pruning residue; $\mathrm{CC}+\mathrm{PR}=$ cover crop plus pruning residue.

\section{Discussion}

\subsection{Soil Nitrate Evolution}

The results highlight, as expected, the prominent effect of fertilization on the soil nitrate content. In comparison, cover cropping and pruning residue incorporation had much smaller effects.

Data show (Figures 3 and 4) that in F plots and in the first year (2010), CT and CT + PR presented, during the entire period, $\mathrm{NO}_{3}-\mathrm{N}$ values higher, up to fourfold, than cover crop managements (CC and CC + PR), with mean annual (2010) values of 41.6, 36.2, 11.4, and $15.4 \mathrm{~kg} \mathrm{ha}^{-1}$ of $\mathrm{NO}_{3}-\mathrm{N}$ for $\mathrm{CT}, \mathrm{CT}+\mathrm{PR}, \mathrm{CC}$, and CC + PR, respectively.

In contrast, 2011 had much lower mean soil nitrate values and less variability. Additionally, while the mean annual $\mathrm{NO}_{3}-\mathrm{N}$ content diminished from 2010 to 2011 for $\mathrm{CT}$ and $\mathrm{CT}+\mathrm{PR}$, it increased for $\mathrm{CC}$ and $\mathrm{CC}+\mathrm{PR}$, with a significant change in the $\mathrm{NO}_{3}-\mathrm{N}$ ranking among the SMs (in 2010: CT > CT + PR > CC + PR > CC; in 2011: $\mathrm{CT}+\mathrm{PR}>\mathrm{CC}>\mathrm{CT}>\mathrm{CC}+\mathrm{PR})$. The most significant increase between 2010 and 2011 was observed for CC $(+118 \%)$ and the most significant decrease was observed for CT $(-55 \%)$. Comparing UF to $\mathrm{F}$ vines, together with a generalized less average $\mathrm{NO}_{3}-\mathrm{N}$ avail- 
ability in the former $(-62 \%)$, again CC and CC + PR showed an increase $(+20 \%$ and $+56 \%$, respectively) between 2010 and 2011, whereas a considerable decrease was presented by $\mathrm{CT}$ and $\mathrm{CT}+\mathrm{PR}$ ( -56 and $-75 \%$, respectively). In UF plots, the $\mathrm{NO}_{3}-\mathrm{N}$ content ranking in 2010 was the same as in F plots but different the year after (CC + PR > CT $>C C>C T+P R)$.

A reduction in soil $\mathrm{N}$ availability induced by cover cropping has been variously reported in the literature $[6,20,38]$. Previous research carried out in Sicily in a rain-fed vineyard showed a better effect on the grape yield of temporary cover crop rather than of permanent cover crop [39]. Soil $\mathrm{NO}_{3}-\mathrm{N}$ reduction may be more evident in permanent cover crops such as Festuca arundinacea or temporary cover crops that are grasses [40,41]. In California vineyards, soil $\mathrm{NO}_{3}-\mathrm{N}$ is consistently greater in cultivated soils than in cereal cover crop treatments [6]. However, research in Sicily in an unfertilized Merlot vineyard indicated that the soil $\mathrm{NO}_{3}-\mathrm{N}$ content is lower in conventionally managed plots than in plots with leguminous cover crops [13].

Conversely, our results indicated a significant shift in the effect of soil management over time (from the first to the second year) on the average annual $\mathrm{NO}_{3}-\mathrm{N}$ content in the soil, i.e., a decrease in CT and CT + PR and an increase in CC and CC + PR, that can likely be interpreted in terms of both cumulative effects from one year to the next and transitional effects from one soil management regime to another [41]. Similarly, in research designed to study the effects on the soil $\mathrm{NO}_{3}-\mathrm{N}$ availability of two different cover crops (leguminous vs. gramineous) in a Spanish vineyard (cv. Tempranillo) over three years, while the barley cover reduced the availability of soil $\mathrm{NO}_{3}-\mathrm{N}$ compared to conventional tillage from the first year, the clover cover, instead, reduced $\mathrm{NO}_{3}-\mathrm{N}$ only temporarily but increased it afterward [42].

These apparent contradictions underline the involvement of other phenomena including $\mathrm{N}$ fixation, the mineralization processes of cover crop and pruning wood biomass [14], and $\mathrm{NO}_{3}-\mathrm{N}$ recycling and immobilization by soil microorganisms under cover crop [6]. Additionally, the direct and indirect effects of early competition for water and $\mathrm{N}$ resources between cover crop and the grapevine since bud break cannot be excluded [20,43].

Overall, this also suggests the need to pay necessary attention to temporal differences in the absorption kinetics of the cover crop and the vine [40].

The high variation of the results that we found between $F$ and UF vines and between years indicates, on the one hand, the paramount effect exerted by fertilization and, on the other hand, the existence of carry-over effects of the previous year's vineyard floor management practice [38]. In fact, regardless of the applied management treatments, the overall variation of $\mathrm{NO}_{3}-\mathrm{N}$ availability in the two years was less pronounced in $\mathrm{F}(-17 \%)$ than in UF $(-37 \%)$ plots where factors other than fertilization could emerge. Looking at the variation of $\mathrm{NO}_{3}-\mathrm{N}$ availability as influenced by management treatments, the only increase observed between 2010 and 2011 (in CC and CC + PR) in both F and UF plots can likely be due to the cumulative effect over the course of time of either cover crop and vine biomass incorporation. An improved soil organic matter content and mineralization could positively have determined in these cases the increase in soil $\mathrm{NO}_{3}-\mathrm{N}$ availability from year to year. A positive improvement of soil quality determined by an increase in soil organic matter and the soil $\mathrm{N}$ content has been evidenced by the use of annual crops in fruit orchards in several cases, including vineyards under Mediterranean conditions [44,45]. On the contrary, the generalized decrease in $\mathrm{NO}_{3}-\mathrm{N}$ availability in $\mathrm{CT}$ and $\mathrm{CT}+\mathrm{PR}$ is possibly related due to the higher organic matter mineralization rate and loss by $\mathrm{NO}_{3}-\mathrm{N}$ leaching fostered by tillage [14] and not compensated, at least in the short term, by the positive effects of soil aggregation promotion and organic carbon preservation expected by the incorporation of plant residues in semiarid Mediterranean agro-ecosystems [46]. Moreover, this result is consistent with the well-known evidence that bare soils in the inter-canopy area of orchards are more susceptible to organic carbon mineralization and that cover cropping, by modifying the water regime of the vineyard, contributes to a faster decrease in and a premature arrest of $\mathrm{N}$ mineralization during summer $[13,20]$.

The soil $\mathrm{NO}_{3}-\mathrm{N}$ seasonal trend must be related to the vine phenological stages. 
In $V$. vinifera, the periods of greatest $\mathrm{N}$ requirement coincide with the phase of berry active growth, between 80 and 130 days after bud break, and therefore in a more advanced period than in spring $[35,47]$. Similarly, in V. labruscana Bailey Concord grape, significant N uptake has been reported before and after veraison [48].

In our study, during early spring, we generally observed an increase in the soil $\mathrm{NO}_{3}-\mathrm{N}$ content, further enhanced in F plots by fertilization (Figures 3 and 4). Soon after bud break (31 March-3 April) and until fruit set (2 June), a decrease in such content can be related to increasing vine $\mathrm{N}$ uptake. At fruit set, a general inflection of the $\mathrm{NO}_{3}-\mathrm{N}$ soil content can be observed. Afterward, in summer, after a second phase of $\mathrm{NO}_{3}-\mathrm{N}$ increase, a sharp decrease following harvest time (12 September) can be observed until winter. In other words, it seems that the highest vine $\mathrm{N}$ uptake follows soon after the peaks in the $\mathrm{NO}_{3}-\mathrm{N}$ soil content.

These trends are in agreement with several studies regarding grapevine seasonal $\mathrm{N}$ uptake, which report two distinct absorption peaks, i.e., bud break-veraison and harvest time-leaf fall $[35,36]$. Furthermore, a low $\mathrm{N}$ content in soil since bud break and a similar minimum in the soil $\mathrm{NO}_{3}-\mathrm{N}$ at fruit set was found in Mediterranean vineyards in France [20,38]. Additionally, it is worth highlighting that until bud break, a grapevine uses the $\mathrm{N}$ stock previously accumulated in the permanent organs of the plant (roots and woody tissues) to sustain the rapid shoot growth phase. Subsequently, vines replenish their $\mathrm{N}$ reserves mostly post-harvest, actively absorbing $\mathrm{N}$ from the soil $[36,48,49]$. This last intense root activity preceding vine dormancy [50] leads to the soil $\mathrm{N}$ reserve depletion observed in winter. In the case of temporary winter cover cropping, as in our case, this intense $\mathrm{N} \mathrm{ab}$ sorption is a little or not influenced by cover crop competition. A similar strong decrease in soil $\mathrm{NO}_{3}-\mathrm{N}$ content in winter has been observed in a Chardonnay vineyard in California's Mediterranean climate in the absence of substantial cover crop and weed growth and has been attributed to leaching or trace gas efflux in response to precipitation [6].

\subsection{Effects on the Grapevine}

In our study, no influence of the imposed soil managements on the grapevine phenology was detected. This result confirms that factors such as temperature and photoperiod, differently than those considered ( $\mathrm{N}$ fertilization and soil management), are the most effective drivers in determining grapevine phenological development [51].

Concerning the vine $\mathrm{N}$ content, the results appeared consistent with the abovereported consideration of soil $\mathrm{NO}_{3}-\mathrm{N}$ trends. In particular, (i) a greater total amount of $\mathrm{N}$ in the aerial biomass (grapes, shoots, leaves) of Grecanico dorato during $2010 \mathrm{com}$ pared to 2011, consistent with the greater $\mathrm{NO}_{3}-\mathrm{N}$ amount in the soil in the first year, and (ii) a greater total $\mathrm{N}$ amount in $\mathrm{F}$ than in UF vines, consistent with the differences observed in the soil $\mathrm{NO}_{3}-\mathrm{N}$ content between years, could be observed. Vines in $\mathrm{CC}$ plots had the lowest total N content in F and UF plots in 2010 and in F plots in 2011. On the contrary, the highest total $\mathrm{N}$ content in the aerial biomass, except for 2010 in F plots, was found in grapevines in CC + PR.

Bud fertility and grape yield increased when cover crop and vine pruning residue burial were combined (CC + PR), regardless of the adoption of chemical fertilization. However, the combination of urea fertilization with the spring burial of cover crop plus vine pruning residues $(\mathrm{CC}+\mathrm{PR})$ and the parallel high $\mathrm{N}$ amount detected in the aerial biomass resulted in a further increase in vine shoot vigor that may not be necessarily favorable to a balanced relationship between vegetative and productive grapevine activities $[20,34,50]$.

This last finding confirms other authors' observation that supplemental $\mathrm{N}$ fertilization is not necessary when a leguminous winter cover crop is adopted, and a sufficient level of organic matter into the soil is ensured [36]. On the contrary, in CT and CT + PR, in comparison to $\mathrm{CC}$, an excess of available $\mathrm{NO}_{3}-\mathrm{N}$ in the soil can likely occur.

Both $\mathrm{N}$ deficiency and $\mathrm{N}$ excess affect grapevine performance, including must properties ([50] and references therein). Vegetative growth, photosynthetic activity, and $\mathrm{N}$ content in berries (and related wine fermentability and quality) are inversely correlated with $\mathrm{N}$ 
deficiency [52]. Conversely, excessive $\mathrm{N}$ supply causes excessive grapevine vigor and, ultimately, can negatively affect the canopy architecture and bunch microclimate, delay berry maturity, and increase the incidence of Botrytis bunch rot [53].

Under the tested conditions, the effects of a limited $\mathrm{N}$ stress were observed only in $\mathrm{CC}$, whereas conditions of potential $\mathrm{N}$ excess could be deduced by the general high level of pruning wood (1.02 kg vine $^{-1}$ on average) and yields (3.5 $\mathrm{kg}$ vine $\mathrm{e}^{-1}$ on average). In our results, grapevines in CC presented the lowest values of fertility, yield, $\mathrm{DW}_{\mathrm{gsl}}$, and TSS, whereas grapevines in CC + PR presented quite the opposite values. Furthermore, the existence of a potential imbalance (overgrowth) between vegetative and productive grapevine activities was suggested by the Ravaz index that was particularly low in CC in both F and UF vines. Indeed, low Ravaz index values, well below the optimal value (5.0) proposed in the literature [54], were generally observed for all soil managements. As a whole, it has to be noted that the high values of yield generally obtained $\left(15 \mathrm{tha}^{-1}\right)$, in relation to even higher average values of pruning wood, led to these low Ravaz index values ( 3.6 on average) and can be related to the fertile agronomic environment and the vigorous scion-rootstock combination in our study. In this regard, it is noteworthy that the low Ravaz index and the yield we generally obtained leave the vineyard with a sufficient margin of resilience in the occurrence of even higher competition events, considering the Menfi wines PDO yield limit (12 $\mathrm{t} \mathrm{ha}^{-1}$ year $^{-1}$ ).

YAN was significantly influenced by both fertilization and soil management treatment. A potential detrimental effect of cover cropping adoption on YAN and, consequently, on wine quality is variously documented [42,52,55], even if variable effects can be expected in relation to many factors such as the type of soil management adopted, the cover crop species, and also the scion-rootstock combination [56]. However, all the values we found, although higher in F plots than in UF plots, were well above the baseline YAN value generally recommended, i.e., $140-250 \mathrm{mg} \mathrm{L}^{-1}[52,57,58]$, probably also due to the inherent vigor characteristics of the 140 Ruggeri rootstock in our vineyard, as reported elsewhere [56].

\section{Conclusions}

The present study was conducted within a mature commercial vineyard in a Mediterranean climate viticultural area, on fertile soil, and with a productive and vigorous scionrootstock combination, under rain-fed cultivation conditions. Our findings highlight that temporary winter leguminous cover crops, fertilization with urea, and pruning residue burial are all able to significantly influence relevant grapevine parameters such as vegetative growth, yield, and must composition. Additionally, it emerged from the study that a combination of leguminous cover cropping and pruning residue burial might represent a reliable, sustainable tool to ensure soil nitrate availability to the vine. Moreover, these sustainable practices can be usefully applied in rain-fed vineyards under semiarid Mediterranean conditions to reduce or even exclude external $\mathrm{N}$ input, without detrimental effects on the vineyard. Even if the present study was merely designed to investigate the seasonal evolution of soil nitrate and vine performance in the short term, as affected by floor management and fertilization options, it is likely expected that long-term application of these sustainable practices may lead to greater agronomic, yield, and environmental benefits, especially in terms of reducing the risk of nitrate pollution. However, further research is still needed in order to detect the eventual emergence of any effects of buried pruning residue on the dissemination of wood diseases and, over the course of time, of excessive competition between vines and cover crops for soil resource acquisition.

Supplementary Materials: The following are available online at https: / www.mdpi.com/2073-439 5/11/1/164/s1, Table S1: Mean daily temperature $\left({ }^{\circ} \mathrm{C}\right)$ and total monthly rainfall (mm) (2009-2011), at San Marco, Sicily, 37.325N, 13.002E; Table S2: Values of Nitrogen inputs $\left(\mathrm{kg} \mathrm{ha}^{-1}\right)$ provided by cover crop (CC) biomass and vine Pruning Residue (PR) biomass \pm standard deviation.

Author Contributions: Conceptualization, L.G.; data curation, A.N., A.P., and M.G.B.; formal analysis, L.G.; investigation, A.S.; methodology, V.A.L. and A.S.; supervision, E.B.; visualization, A.N.; 
validation, A.P. and M.G.B.; roles/writing-original draft, A.N., A.P., and M.G.B.; and writingreview and editing, L.G., E.B., and R.D.L. All authors have read and agreed to the published version of the manuscript.

Funding: This research received no external funding.

Institutional Review Board Statement: Not applicable.

Informed Consent Statement: Not applicable.

Data Availability Statement: The data presented in this study are available on request from the corresponding author.

Conflicts of Interest: The authors declare no conflict of interest.

\section{References}

1. Ramos, C.; Agut, A.; Lidon, A.L. Nitrate leaching in important crops of the Valencian Community region (Spain). Environ. Pollut. 2002, 118, 215-223. [CrossRef]

2. Montanaro, G.; Xiloyannis, C.; Nuzzo, V.; Dichio, B. Orchard management, soil organic carbon and ecosystem services in Mediterranean fruit tree crops. Sci. Hortic. 2017, 217, 92-101. [CrossRef]

3. Crescimanno, G.; Garofalo, P. Management of irrigation with saline water in cracking clay soils. Soil Sci. Soc. Am. J. 2006, 70, 1774-1787. [CrossRef]

4. Pisciotta, A.; Di Lorenzo, R.; Santalucia, G.; Barbagallo, M.G. Response of grapevine (Cabernet Sauvignon cv) to above ground and subsurface drip irrigation under arid conditions. Agric. Water Manag. 2018, 197, 122-131. [CrossRef]

5. Baiamonte, G.; Minacapilli, M.; Novara, A.; Gristina, L. Time scale effects and interactions of rainfall erosivity and cover management factors on vineyard soil loss erosion in the semi-arid area of southern Sicily. Water 2019, 11, 978. [CrossRef]

6. Steenwerth, K.; Belina, K.M. Cover crops and cultivation: Impacts on soil N dynamics and microbiological function in a Mediterranean vineyard agroecosystem. Appl. Soil Ecol. 2008, 40, 370-380. [CrossRef]

7. Novara, A.; Stallone, G.; Cerdà, A.; Gristina, L. The effect of Shallow Tillage on soil erosion in a semi-arid vineyard. Agronomy 2019, 9, 257. [CrossRef]

8. Rodrigo-Comino, J. Five decades of soil erosion research in "terroir". The State-of-the-Art. Earth Sci. Rev. 2018, 179, 436-447. [CrossRef]

9. Keesstra, S.; Nunes, J.; Novara, A.; Finger, D.; Avelar, D.; Kalantari, Z.; Cerdà, A. The superior effect of nature based solutions in land management for enhancing ecosystem services. Sci. Total Environ. 2018, 610-611, 997-1009. [CrossRef]

10. Galati, A.; Gristina, L.; Crescimanno, M.; Barone, E.; Novara, A. Towards More Efficient Incentives for Agri-environment Measures in Degraded and Eroded Vineyards. Land Degrad. Dev. 2015, 26, 557-564. [CrossRef]

11. Ingels, C.A.; Bugg, R.L.; McGourty, G.T.; Christensen, L.P. Cover Cropping in Vineyards: A Grower's Handbook; Publication 3338; University of California. Division of Agriculture and Natural Resources: Oakland, CA, USA, 1998; ISBN 1-879906-35-X.

12. Nicolás, C.; Masciandaro, G.; Hernandez, T.; Garcia, C. Chemical-Structural Changes of Organic Matter in a Semi-Arid Soil After Organic Amendment. Pedosphere 2012, 22, 283-293. [CrossRef]

13. Novara, A.; Gristina, L.; Guaitoli, F.; Santoro, A.; Cerdà, A. Managing soil nitrate with cover crops and buffer strips in Sicilian vineyards. Solid Earth 2013, 4, 255-262. [CrossRef]

14. Ćupina, B.; Manojlović, M.; Krstić, D.J.; Ĉabilovski, R.; Mikić, A.; Ignjatović-Ćupina, A.; Erić, P. Effect of winter cover crops on the dynamics of soil mineral nitrogen and yield and quality of Sudan grass [Sorghum bicolor (L.) Moench]. Aust. J. Crop Sci. 2011, 5, 839-845.

15. Tonitto, C.; David, M.B.; Drinkwater, L.E. Replacing bare fallows with cover crops in fertilizer-intensive cropping systems: A meta-analysis of crop yield and N dynamics. Agric. Ecosyst. Environ. 2006, 112, 58-72. [CrossRef]

16. García-Díaz, A.; Bienes, R.; Sastre, B.; Novara, A.; Gristina, L.; Cerdà, A. Nitrogen losses in vineyards under different types of soil groundcover. A field runoff simulator approach in central Spain. Agric. Ecosyst. Environ. 2017, 236, 256-267. [CrossRef]

17. Robinson, J.B. Grapevine Nutrition. In Viticulture; Coombe, B.G., Dry, P.R., Eds.; Practices, Winetitles: Adelaide, Australia, 1992; Volume 2.

18. Conradie, W.J. Partitioning of mineral nutrients and timing of fertilizer applications for optimum efficiency. In Proceedings of the Soil Environment and Vine Mineral Nutrition Symposium, San Diego, CA, USA, 29-30 June 2005; Christensen, L.P., Smart, D.R., Eds.; American Society of Enology and Viticulture: Davis, CA, USA, 2005; pp. 69-81.

19. Williams, L.E.; Matthews, M.A. Grapevine. In Irrigation of Agricultural Crops; Stewart, B.A., Nielsen, D.R., Eds.; Agronomy Monograph No. 30; ASA-CSSA-SSSA: Madison, WI, USA, 1990; pp. 1019-1055.

20. Celette, F.; Findeling, A.; Gary, C. Competition for nitrogen in an unfertilized intercropping system: The case of an association of grapevine and grass cover in a Mediterranean climate. Eur. J. Agron. 2009, 30, 41-51. [CrossRef]

21. Lopes, C.M. Cover crops competition for water in vineyards: Case studies in Mediterranean terroirs. In Proceedings of the 11th International Terroir Congress, McMinnville, OR, USA, 10-14 July 2016; pp. 117-123. 
22. Wermelinger, B.; Koblet, W. Seasonal growth and nitrogen distribution in grapevines leaves, shoots and grapes. Vitis 1990, 29, $15-26$.

23. Guerra, B.; Steenwerth, K. Influence of floor management technique on grapevine growth, disease pressure, and juice and wine composition: A review. Am. J. Enol. Vitic. 2012, 63, 149-164. [CrossRef]

24. IUSS Working Group WRB. World Reference Base for Soil Resources 2014, Update 2015. International Soil Classification System for Naming Soils and Creating Legends for Soil Maps; World Soil Resources Reports No. 106; FAO: Rome, Italy, 2015; ISBN 978-92-5-108370-3.

25. Kottek, M.; Grieser, J.; Beck, C.; Rudolf, B.; Rubel, F. World Map of the Köppen-Geiger climate classification updated. Meteorol. Z. 2006, 15, 259-263. [CrossRef]

26. Crespan, M.; Calò, A.; Giannetto, S.; Sparacio, A.; Storchi, P.; Costacurta, A. "Sangiovese" and "Garganega" are two key varieties of the Italian grapevine assortment evolution. Vitis. J. Grapevine Res. 2008, 47, 97-104.

27. Crespan, M.; Storchi, P.; Migliaro, D. Grapevine Cultivar Mantonico bianco is the Second Parent of the Sicilian Catarratto. Am. J. Enol. Vitic. 2017, 68, 258-262. [CrossRef]

28. Baggiolini, M. Stades reperes de la vigne. Rev. Romande Agric. Vitic. Arboric. 1952, 1, 4-6.

29. Bradstreet, R.B. Kjeldahl Method for Organic Nitrogen. Anal. Chem. 1954, 26, 185-187. [CrossRef]

30. Jackson, D.I.; Lombard, P.B. Environmental and management practices affecting grape composition and wine quality-A review. Am. J. Enol. Vitic. 1992, 44, 409-430.

31. Ravaz, L. Sur la brunissure de la vigne. Les. Comptes Rend. Acad. Sci. 1903, 136, 1276-1278.

32. Shively, C.E.; Henick-Kling, T. Comparison of Two Procedures for Assay of Free Amino Nitrogen. Am. J. Enol. Vitic. 2001, 52, 400-401.

33. Bavaresco, L. La fertilizzazione della vite. In Manuale di Viticoltura; Marenghi, M., Ed.; Edagricole: Bologna, Italy, $2005 ;$ pp. 93-114.

34. Palliotti, A.; Poni, S.; Silvestroni, O. Gestione della nutrizione e della concimazione. In Manuale di Viticoltura; Edagricole: Bologna, Italy, 2018.

35. Conradie, W.J. Seasonal uptake of nutrients by Chenin blanc in sand culture: I. Nitrogen. S. Afr. J. Enol. Vitic. 1980, 1, 59-65. [CrossRef]

36. Conradie, W.J. Utilization of nitrogen by the grape-vine as affected by time of application and soil type. S. Afr. J. Enol. Vitic. 1986, 7, 76-83.

37. SPSS. IBM SPSS Statistics for Windows; Version 21.0.; IBM Corp: Armonk, NY, USA, 2012.

38. Ripoche, A.; Metay, A.; Celette, F.; Gary, C. Changing the soil surface management in vineyards: Immediate and delayed effects on the growth and yield of grapevine. Plant Soil 2011, 339, 259-271. [CrossRef]

39. Gristina, L.; Ferrotti, F.; Poma, I.; Saladino, S.; Barbagallo, M.G.; Costanza, P. Management of subterranean clover, annual medic and vetch for Sicilian vineyard sustainability. In Sustainable Use and Management of Soils-Arid and Semiarid Region; Faz Cano, A., Ortiz Silla, R., Mermut, A.R., Eds.; Advances in Geocology; Catena Verlag: Reiskirchen, Germany, 2005; Volume 36, pp. 103-112.

40. Celette, F.; Gaudin, R.; Gary, C. Spatial and temporal changes to the water regime of a Mediterranean vineyard due to the adoption of cover cropping. Eur. J. Agron. 2008, 29, 153-162. [CrossRef]

41. Pérez-Álvarez, E.P.; Pérez-Sotés, J.L.; García-Escudero, E.; Peregrina, F. Cover Crop Short-Term Effects on Soil NO 3 --N Availability, Nitrogen Nutritional Status, Yield, and Must Quality in a Calcareous Vineyard of the AOC Rioja, Spain. Commun. Soil Sci. Plant Anal. 2013, 44, 711-721. [CrossRef]

42. Pérez-Álvarez, E.P.; Garde-Cerdán, T.; Santamaría, P.; García-Escudero, E.; Peregrina, F. Influence of two different cover crops on soil $\mathrm{N}$ availability, $\mathrm{N}$ nutritional status, and grape yeast-assimilable N (YAN) in a cv. Tempranillo vineyard. Plant Soil 2015, 390, 143-156. [CrossRef]

43. Celette, F.; Gary, C. Dynamics of water and nitrogen stress along the grapevine cycle as affected by cover cropping. Eur. J. Agron. 2013, 45, 142-152. [CrossRef]

44. Morugán-Coronado, A.; Linares, C.; Gómez-López, M.D.; Faz, Á.; Zornoza, R. The impact of intercropping, tillage and fertilizer type on soil and crop yield in fruit orchards under Mediterranean conditions: A meta-analysis of field studies. Agric. Syst. 2020, 178, 102736. [CrossRef]

45. García-Díaz, A.; Allas, R.B.; Gristina, L.; Cerdà, A.; Pereira, P.; Novara, A. Carbon input threshold for soil carbon budget optimization in eroding vineyards. Geoderma 2016, 271, 144-149. [CrossRef]

46. Almagro, M.; Garcia-Franco, N.; Martínez-Mena, M. The potential of reducing tillage frequency and incorporating plant residues as a strategy for climate change mitigation in semiarid Mediterranean agroecosystems. Agric. Ecosyst. Environ. 2017, 246, 210-220. [CrossRef]

47. Holzapfel, B.P.; Smith, J.; Field, S. Seasonal vine nutrient dynamics and distribution of Shiraz grapevines. OENO One 2019, 2, 363-372. [CrossRef]

48. Pradubsuk, S.; Davenport, J.R. Seasonal Uptake and Partitioning of Macronutrients in Mature 'Concord' Grape. J. Amer. Soc. Hort. Sci. 2010, 135, 474-483. [CrossRef]

49. Zapata, C.; Deléens, E.; Chaillou, S.; Magné, C. Partitioning and mobilization of starch and N reserves in grapevine (Vitis vinifera L.). J. Plant Physiol. 2004, 161, 1031-1040. [CrossRef]

50. Vrignon-Brenas, S.; Metay, A.; Leporatti, R.; Gharibi, S.; Fraga, A.; Dauzat, M.; Rolland, G.; Pellegrino, A. Gradual responses of grapevine yield components and carbon status to nitrogen supply. OENO One 2019, 2, 289-306. [CrossRef] 
51. Prats-Llinàs, M.T.; Nieto, H.; DeJong, T.M.; Girona, J.; Marsal, J. Using forced regrowth to manipulate Chardonnay grapevine (Vitis vinifera L.) development to evaluate phenological stage responses to temperature. Sci. Hortic. 2020, 262, 109065. [CrossRef]

52. Bell, S.J.; Henschke, P.A. Implications of nitrogen nutrition for grapes, fermentation and wine. Aust. J. Grape Wine Res. 2005, 11, 242-295. [CrossRef]

53. Keller, M. Deficit Irrigation and Vine Mineral Nutrition. Am. J. Enol. Vitic. 2005, 56, 267-283. [CrossRef]

54. Bravdo, B.; Hepner, Y.; Loinger, C.; Cohen, S.; Tabacman, H. Effect of crop level and crop load on growth, yield, must and wine composition, and quality of Cabernet Sauvignon. Am. J. Enol. Vitic. 1985, 36, 125-131.

55. Giese, G.; Wolf, T.K.; Velasco-Cruz, C.; Roberts, L.; Heitman, J. Cover crop and root pruning impacts on vegetative growth, crop yield components, and grape composition of Cabernet Sauvignon. Am. J. Enol. Vitic. 2015, 66, 212-226. [CrossRef]

56. Lee, J.; Steenwerth, K.L. Rootstock and vineyard floor management influence on "Cabernet Sauvignon" grape yeast assimilable nitrogen (YAN). Food Chem. 2011, 127, 926-933. [CrossRef]

57. Spayd, S.E.; Wample, R.L.; Evans, R.G.; Stevens, R.G.; Seymour, B.J.; Nagel, C.W. Nitrogen Fertilization of White Riesling Grapes in Washington. Must and Wine Composition. Am. J. Enol. Vitic. 1994, 45, 34-42.

58. Bely, M.; Sablayrolles, J.; Barre, P. Automatic detection of assimilable nitrogen deficiencies during alcoholic fermentation in oenological conditions. J. Ferment. Bioeng. 1990, 70, 246-252. [CrossRef] 